\title{
Study of Core Competency Elements and Factors Affecting Performance Efficiency of Government Teachers in Northeastern Thailand
}

\author{
Pacharawit Chansirisira ${ }^{1}$ \\ ${ }^{1}$ Department of Educational Administration, Faculty of Education, Mahasarakham University, Thailand \\ Correspondence: Pacharawit Chansirisira, Department of Educational Administration, Faculty of Education, \\ Mahasarakham University, Mueang District, Maha Sarakham 44000, Thailand. E-mail: wittaya.c@msu.ac.th
}

Received: September 9, 2012 Accepted: September 28, 2012 Online Published: October 12,2012

doi:10.5539/ies.v5n6p161

URL: http://dx.doi.org/10.5539/ies.v5n6p161

\begin{abstract}
The research aimed to investigate the core competency elements and the factors affecting the performance efficiency of the civil service teachers in the northeastern region, Thailand. The research procedure consisted of two steps. In the first step, the data were collected using a questionnaire with the reliability (Cronbach's Alpha) of .90. The sample size was specified based on Krejcie and Morgan's table and 352 samples were selected using the simple random sampling technique. The second step involved an in-depth interview of 10 specialists to gain the ways to develop effective performance competency and the statistics used for data analysis included percentage, standard deviation, and descriptive analysis. The questionnaire results revealed that there were 11 elements of 4 core competencies. There were 2 elements for the achievement motivation competency, 3 elements for the service mind competency, 3 elements for the team work competency, and 3 elements for the self-development competency. For appropriate ways to develop core competencies for effective performance of civil service teachers, there were 13 ways which included understanding of related environment, supporting of working resources, having effective management system, reducing losses at work, creating good working atmosphere, promoting participation in decision making, supporting staff for professional development, communicating openly within the organizations, listening to the opinions of others, developing of quality system in work, creating good human relations among staff, building morale in the workplace, and specifying appropriate working patterns.
\end{abstract}

Keywords: competency elements, core competency, civil service teachers, factors for efficiency

\section{Introducation}

Performance efficiency is the key to the success of an organization. Whether an organization will gain satisfactory outcomes in terms of production, service, progress as well as customer and staff satisfaction is very much dependent upon the ability of the organization to develop it's the organization's efficiency (Luksana. 1999).

To manage things efficiently and successfully, organizations desperately need to rely on "manpower" which is regarded as one of the most important resources. Meanwhile every organization is attempting so hard to develop appropriate performance measures of human resources. It is widely accepted that the organization's success and progress is dependent directly on efficient valuable workers. In reality, however, organizations often fail to keep their valuable human resources. Improving working conditions of the staff is a good way to create morale in the workplace, one of the basic needs and expectations of workers. Besides, morale in the workplace also shows a link between job satisfaction and organizational competency (Huse \& Cummings.1985). Thus, the organization should take into consideration the life quality of its staff, and at the same time try to find the ways to improve performance efficiency to achieve its established goals.

To create effective management system as specified in the mission of the organization, it requires not only the administrators who have good visions, knowledge and administrative skills but also efficient workers who function as the main mechanism to help cooperate with the administrators to reach the organization's goals (Chansiri. 2008). In the globalized world, it has become more and more competitive among organizations at all levels - from regional to international. According to Casitllo, competencies are crucial factors affecting the 
organization's competitive abilities (Casitllo. 2005). As a result, it is necessary that organizations understand what make effective management system. Analysis of performance of an individual or a team, search of workers with excellent performance as well as identifying essential skills that the workers should have are the key factors that will help the organization achieve its goal. Greengard (1999) and David C. McCleland (1973) mentioned that IQ which consists of aptitude, academic proficiency, knowledge, and determination to succeed is not a good indicator of success at work, but competency. This clearly reflects that a good worker is not always a person with excellent knowledge, but rather a person who knows how to apply the knowledge he or she has into work for benefits and success of his or her job. Such a person is said to have a job competency. The person who has good life management skills is the person who has high competency. Many research studies revealed that such competency can be developed, created and implanted in a person by means of appropriate education (Sripudtha. 2005).

For effective educational management, competency is one of the key factors to reach the development goals. However, nowadays, numerous civil service teachers and educational personnel have limited opportunities for sustainable self development. Since all staff members in all levels are important to the organization, when one group of the staff members fails to develop their competency, the other groups will be affected as well. Thus, it is obvious that many civil service teachers and educational personnel are very much in need of self development. Having good life and working conditions help to create morale in work which is one of the basic needs and expectations of individual workers. The outcomes of the organization should go along with the staff's satisfaction. Good working conditions help the organization in many positive ways such as a larger amount of production, morale in work, motivation for professional development and, of course, performance efficiency (Huse and Cummings. 1985). The organization has therefore to be responsible for improving the life quality of its staff as well as choosing the right method to increase work performance for the successful results as expected.

On the whole, the researcher would like to study the core competency elements and factors that affect performance efficiency of the civil service teachers along with educational administrators and personnel in the Northeastern region, Thailand. The researcher hopes very much that the study results would be useful and beneficial to the administrators in organizations or institutions for their further development.

\section{Purposes of the Study}

1) To investigate the core competency elements of the civil service teachers in the Northeastern region, Thailand.

2) To study the opinions of the civil service teachers, administrators and personnel about the core competency factors that affect performance efficiency of the civil service teachers in the region.

3) To provide appropriate ways to improve performance efficiency of civil service teachers.

\section{Framework of the Study}

The framework of this study involves:

1) The core competencies investigated in this study are based on the Core Competency Development framework by Office of the Teacher Civil Service Educational Personnel Commission (Faculty of Education, Mahasarakham University. 2006: 140-148): the 4 competencies civil service teachers are expected to have consist of achievement motivation competency, team work competency, self-development competency, and service mind competency.

2) There are 8 factors influencing performance efficiency, namely, compensation, clean and safe environment, performance development, promotion and security, social relations, management patterns, balance between work and lifestyle, and community responsibility.

\section{Methodology}

1) Population: the population of the study consisted of 178, 392 civil service teachers and educational personnel under the Office of Basic Education Commission in Northeastern Thailand.

2) Sample: The sample size was specified based on Krejcie and Morgan's table (Krejcie and Morgan. 1970) and 500 participants were selected by the following techniques:

(i) There are totally 19 provinces in the northeast region and 5 provinces (Maha Sarakahm, Surin, Burirum, Chaiyabhum, and Udonthani) were chosen using purposive sampling technique.

(ii) The sample group of 500 people was selected using quota sampling technique, and was later divided into two groups: 360 civil service teachers and 140 educational administrators and personnel (such as 
vice-directors, supervisors). 500 copies of a questionnaire were sent out and 352 were returned (70.40\%).

\section{Procedure}

The research procedure involves 3 steps as follows:

Step 1: studying the 4 core competency elements using a questionnaire (section 2), and analyzing core competency factors affecting performance efficiency of civil service teachers using a questionnaire (section 3).

Step 2: Creating a structured questionnaire about ways to improve the core competencies for development of performance efficiency of civil service teachers. The created questionnaire was presented to 10 specialists (administrators and teachers) to check the appropriateness of the contents.

Step 3: Analyzing data and writing a complete report.

\section{Analysis of Data}

The data were collected through the questionnaire and analyzed by using statistics as outlined below:

1) General data were analyzed by using frequency and percentage.

2) Performance efficiency was analyzed following level of performance efficiency by using mean and standard deviation (Srisa-art. 2003). The following is the interpretation of performance efficiency into different levels.

$\begin{array}{ll}\text { Score } & \text { Meaning } \\ 4.51-5.00 & \text { highest } \\ 3.51-4.50 & \text { high } \\ 2.51-3.50 & \text { medium } \\ 1.51-2.50 & \text { low } \\ 1.00-1.50 & \text { lowest }\end{array}$

3) There is a calculation of the intercorrelation coefficiency of the independent variables (gender, education, and job position) and the dependent variable (performance efficiency).

4) Calculation of the intercorrelation coefficiency of the independent variables and the constant value, to formulate forecasting equations by using stepwise multiple regression analysis.

\section{Results}

1) The results of the analysis of the educational administrators and personnel and civil service teachers' opinions on the core competency elements of performance efficiency of the civil service teacher civil service teachers under the Office of Basic Education Commission in Northeastern Thailand can be shown in Table1.

Table 1. Opinions (in the overall and in separate dimensions) about the core competency elements of the civil service teachers under the Office of Basic Education Commission in the Northeastern

\begin{tabular}{l|c|l|l}
\hline Core competency elements & X & S.D. & Meaning \\
\hline 1. Achievement motivation competency & $\mathbf{3 . 8 4}$ & $\mathbf{0 . 7 2}$ & high \\
1.1 resources management & 3.81 & 0.71 & high \\
1.2 accomplishment & 3.85 & 0.77 & high \\
2. Team work competency & $\mathbf{4 . 0 1}$ & $\mathbf{0 . 6 5}$ & high \\
2.1 working process & 3.92 & 0.67 & high \\
2.2 determination & 4.11 & 0.73 & high \\
2.3 relations among team & 4.00 & 0.69 & high \\
3. Service mind competency & $\mathbf{4 . 0 6}$ & $\mathbf{0 . 6 3}$ & high \\
3.1 service & 4.02 & 0.71 & high \\
3.2 service system ability & 4.00 & 0.65 & high \\
3.3 service ability & 4.17 & 0.67 & high \\
4. Self-development competency & $\mathbf{3 . 9 8}$ & $\mathbf{0 . 6 5}$ & high \\
4.1 enthusiasm to learn new things & 4.03 & 0.72 & high \\
4.2 self-efficacy performance & 4.11 & 0.73 & high \\
4.3 academic \& technological development and application & 3.83 & 0.72 & high \\
\hline Total & $\mathbf{3 . 9 8}$ & $\mathbf{0 . 5 6}$ & high \\
\hline
\end{tabular}


From Table 1 it can be concluded that the overall opinion about the core competency elements of the civil service teachers, administrators and personnel was at a high level. When considering different dimensions it had also a high level of opinion, too. Such dimensions can be ranged from high to low according to the average score: service mind competency $(\overline{\mathrm{X}}=4.06)$ consisting of 3 elements; team work competency $(\overline{\mathrm{X}}=4.01), 3$ elements; self-development competency $\overline{\mathrm{X}}=3.98), 3$ elements and; achievement motivation competency $(\overline{\mathrm{X}}=3.84), 2$ elements.

2) The results of the interview with 10 specialists: There are 13 ways suggested by the specialists to improve performance efficiency of civil service teachers including 1) understanding of related environment, 2) supporting of working resources, 3) having effective management system, 4) reducing losses at work, 5) creating good working atmosphere, 6) promoting participation in decision making, 7) supporting staff for professional development, 8) communicating openly within the organizations, 9) listening to the opinions of others, 10) development of quality system in work such as TQA, TQM, BSC, QA, ISO, RMB, PDCA, 11) creating good human relations among staff, 12) creating morale in work and, 13) specifying appropriate working patterns.

\section{Discussion}

The results of the analysis of factors affecting the performance efficiency of the civil service teachers in Northeastern Thailand may be discussed as follows:

The civil service teachers and educational personnel revealed the opinion on the elements of core competencies at a high level. These competencies are specified by the Office of the Teacher Civil Service and Educational Personnel Commission for civil service teachers and educational personnel at all levels. As a result, the civil service teachers paid attention mainly to the competencies specified by the commission, particularly the first two competencies: service mind and team working competencies. This might be because the civil service teachers viewed that teaching was their main duty. Having good learning and teaching system and the ability to transfer knowledge to the students were part of service mind. The team working strategy takes an important role in organizational management. It has become one of the most useful working and administration patterns for an individual and an organization. The civil service teachers have to know and understand the principles of team working. They have to understand the team working techniques including organizational communication, cooperation, brainstorming, and problem solving. Team working is good in that it leads to transparency and knowledge management within the team. The civil service teachers have to become a role model for team working and a leader in leading the organization to be a team working organization. In addition, they should have the communicative ability and the ability to build team work, cooperation, and good working atmosphere. They should also be able to apply their talent to develop their work, themselves, and their profession (Bowman. 2002). The organization has to acknowledge the importance of team working. In a successful organization, the staff members, working as a team, enable the organization to achieve its goals efficiently. This finding is in line with the study of Weller (2001), which found that one of the knowledge and skills that enabled the department heads to successfully administrate the department was team working and Wright (2001) also found that the main strategy for the movement and mechanism of the organization was interpersonal and team working skills. Meisingers (2003) emphasized that one of the five important competencies for an organization was team working.

The achievement competency revealed the lowest opinion score. This is probably because the achievement competency focusses on the working to meet the civil service teacher's working standards and the civil service teachers under study have already done this, so they did not pay much attention to it. This finding is in line with the study of Limaree (2009), which studied the core competencies of educational personnel in the educational service area 3, Khon Kaen Province, Thailand and found that the achievement competency showed the lowest score. Luanprasert (2009) also studied the core competencies of the educational personnel in the educational service area 3 Song Khla Province, Thailand and found that the competency that showed the lowest score and needed improvement the most was the achievement competency.

The civil service teachers and educational personnel have the opinion towards the factors affecting working efficiency in general at a high level. The first three highest scores were social responsibility, staff development, and management, respectively. This might be because the civil service teachers and educational personnel viewed that social responsibility is a public factor; when a person is socially responsible, he or she will be able to perform other duties effectively. This idea is compatible with the findings of Satchathamnukul (2003), which studied the opinions on life quality of bankers in the Government Saving Bank in Bangkok and found that the bankers saw social responsibility and society's benefits as the priority. Aumphan (2007) also studied life quality 
of civil servants in Department of Alternative Energy and Efficiency, Ministry of Energy, Thailand and found that social integration, team working, society's benefits, and social responsibility were shown at a high level.

For the correlation between independent variables and all core competencies, it was found that the correlation between the independent variables that are the factors of the four core competencies, which includes teamwork, self-development, achievement motivation, and service mind, revealed positive effects on work efficiency with the significance level of 0.05 and the correlation coefficient between $0.378-0.845$.This is probably because the 4 core competencies are set to be the shared characteristics of the staff members in the whole educational system to help shape the shared values and expected behaviors of the staff in the system (OCSC. 2005). As the correlation coefficients in all dimensions were highly positive, it reflects that the 4 core competencies are correlated and supportive to one another for performance efficiency and success. The findings thus emphasize that all core competencies affect the performance efficiency of the civil service teachers and educational personnel in the Northeastern region of Thailand. Moreover, the results also support the hypothesis, which states that all core competencies help predict the performance efficiency of the civil service teachers and educational personnel. When calculating the correlation coefficient values of prediction of all core competencies using regression analysis, the $\operatorname{AdjR}^{2}$ value was 66.50 , which was a fairly good. However, the rest of the prediction value $(33.50 \%)$ cannot be explained by using the 4 core competency variables.

\section{Suggestions}

\section{Suggestions for policy development}

1) Besides the 4 core competencies, other competencies should be taken into consideration. Organizations should encourage constant self development of staff members for effective and good work performance.

2) It is suggested that the branches of Office of the Basic Education Commission in the Northeastern systematically and continuously develop policy, plan or project for more effective and efficient performance of the civil service teachers and educational personnel.

3) The regional branches of Office of the Basic Education Commission in Northeastern Thailand should share knowledge and information gained from this study with educational administrators and related persons for a better understanding of the core competency elements and factors affecting performance efficiency. It should also give constant enthusiastic support for the most effective performance efficiency of civil service teachers and staff.

\section{Suggestions for further studies}

1) An action research should be conducted for in-depth investigation of competencies of the civil service teachers in such numerous ways as core competency, specific work type competency, and management competency, etc.

2) A future study should be carried out to examine and compare core competencies of civil service teachers, administrators and educational personnel at different schools that are varied in size, location, school and type (Best Practice schools, ordinary schools.

\section{Acknowledgements}

I am so grateful to Faculty of Education, Mahasarakham University for both moral and financial support. I also have to say a huge thank you to all of the participants - Director of Office of Basic Education Commission, school administrators, Supervisors, and teachers- for their insights, enthusiasm, and support.

\section{References}

Ampun, U. (2007). Quality of Life in the Work of the Government's Department of Energy Conservation and Renewable Energy Development, Ministry of Energy. Independent Study (Business Administration), Graduate College, Petchburi. Valaya rajabhat University.

Bowman, R. F. (2002). “The real Work of Department Chair,” The Clearing House, 72(3).

Castillo, E. D. (2005). Defining Competencies. Business Mexico. Mexico. City: Mar.

Chansiri, W. (2008). Core Competency of Public Universities Supporting-Line Administrators in Thailand. Doctor of Education Thesis, Mahasarakham: Mahasarakham University.

Faculty of Education. (2006). Training Documents to "Expert" competency Improvement Teachers and EducationalPersonnel Before Appoint Experts. Mahasarakham: Faculty of Education, Mahasarakham University. 
Greengard, S. (1999). Competency Management Delivers Spectacular Corporate Gains, Workforce. Costa Mesa: March.

Huse, Edgar F., \& Thomas G. Cummings. (1985). Organization Development And change. Third edition. Minnesota: West Publishing.

Krejcie, V., \& D. W. Morgan. (1970). Educational and Psychological Measurement. 608-609.

Laksana S. (2003). Development Performance. Bangkok: Suan Sunandha Rajabhat Institute.

Limaree, S. (2009). The Core Competency of Educational Officers that work in The Office of Basic Education, Khon Kaen, Area, 3. Khon Kaen: Office of Basic Education Khon Kaen Area 3. http://dx.doi.org/10.4321/S1130-14732009000300008

Luanprasert Y. (2009). Core Competency in Practice of Educational Officers in Office of BasicEducational Songkhla Area, 3. Thesis, Master of Art, Songkhla: Thaksin University.

McCleland, D. (1973). "Testing for Competence Rather than for Intelligence," American Psychologist, 28(1), 1-14, June. http://dx.doi.org/10.1037/h0034092

Meisinger, S. (2003). Adding Competencies Adding Value HR Magazine. Alexandria : Jul.

Office of The Civil Service Commission (OCSC). (2005). Thai Civil Service Performance Guide. Bangkok: P. L. Living.

Satchathamnukul B. (2003). The Comments for the Quality of Life of Employees of Omsin Bank in Bangkok. Thesis, Master of Management, Bangkok: Srinakharinwirot University.

Sripadtha S. (2006). Enterpreneureship. Mahasarakham: Rajabhat Mahasarakham University.

Srisa-ard, B. (2003). Research for Teacher. Bangkok: Suveeriyasarn.

Weller, L. D. (2001). "Department Heads: The Most Underutilized Leadership Position," NASSP Bulletin. 85(625), 73-81. http://dx.doi.org/10.1177/019263650108562508

Wright. L. (2001). HR Competencies: Getting Them Right. Canadian HR Reporter. Toronto: Nov 5. 